\title{
Comparison between effectiveness of umbilical cord care using topical breast milk application and dry techniques in accelerating umbilical cord separation and preventing omphalitis
}

\author{
Rina Kartikasari, Hidayat Wijayanegara, Osman Syarief \\ Correspondence: Dr Rina Kartikasari, Student of Applied Midwivery Master Program of \\ STIKes Dharma Husada, Applied Midwivery master Program of STIKes Dharma Husada, \\ Health Polytechnic of Bandung; Email - hanaufzan@gmail.com
}

Distributed under Attribution-NonCommercial - Share Alike 4.0 International (CC BY-NC-SA 4.0)

\begin{abstract}
Objectives: To compare umbilical cord separation time and incidence of omphalitis in newborns receiving three different umbilical cord care techniques: topical breast milk, open dry, and closed dry techniques. Methods: This study was conducted during the period of June-August 2018 on consecutively selected 120 newborns aged 0 days up to 2 days after the release of the umbilical cord. Subjects were divided into three groups based on the umbilical cord care technique used with 40 subjects in each group. Omphalitis incidence was analyzed. Results: Umbilical cord separation was found to be significantly faster in topical breast milk group (2 days faster than in the open dry technique group and four days faster than in the closed dry technique group) with $\mathrm{p}<0.05$. Omphalitis was also significantly prevented more effectively in the topical breast milk and open dry technique groups $(\mathrm{p}<0.05)$. A strong relationship $(\mathrm{r}=0.33)$ was also identified between umbilical cord separation time and infant birth weight with $\mathrm{p}=0.034$. Conclusions: Cord care using topical breast milk is shown to accelerate umbilical cord separation and improve prevention of omphalitis when compared to open dry technique and closed dry technique.
\end{abstract}

Keywords: Closed dry technique, omphalitis, open dry technique, topical breast milk, umbilical cord separation time.

It is estimated that more than a half million of newborns die every year from serious neonatal infections, contributing $15 \%$ of global neonatal deaths from all causes. ${ }^{1,2}$ Around $75 \%$ of neonatal deaths occur in the first week of life with most occur in the first 48 hours. In countries with a very high number of neonatal deaths, half of the deaths are infection related deaths. ${ }^{3}$ It is also discovered that $33 \%$ neonatal tetanus cases are also followed by omphalitis and sepsis. ${ }^{1,4}$ Data from WHO in 2010 presented that 560,000 of neonatal deaths are caused by umbilical cord infections. In Southeast Asia, neonatal deaths due to umbilical cord infections is 126,000 . $^{5,6}$

In an effort to reduce infant mortality due to tetanus it is necessary to provide proper and approriate newborn

Received: $14^{\text {th }}$ Febuary 2019. Accepted: $18^{\text {th }}$ April 2019.

Kartikasari R, Wijayanegara H, Syarief O. Comparison between effectiveness of umbilical cord care using topical breastmilk application and dry techniques in accelerating umbilical cord separation and preventing omphalitis. The New Indian Journal of OBGYN. 2019; 6(1):3-10 
care, especially umbilical cord care, to avoid the risk of infection. ${ }^{6,7}$ In general, umbilical cord care aims to prevent infection and accelerate umbilical cord separation. ${ }^{7,8}$ Since 1998, WHO has recommended that umbilical cord care in newborns should be performed in a clean and dry manner. ${ }^{9,10}$ Likewise, the Indonesian Ministry of Health also recommends open and dry cord care for newborns. ${ }^{11}$

Umbilical cord is the area that is most susceptible to bacteria colonization that may lead to neonatal infections such as sepsis and omphalitis due to its necrotic property. Umbilical cord infection develops after bacterial colonization and is one of the causes of newborn mortality and morbidity in under-developed and developing countries. ${ }^{6}{ }^{12-15}$ Approximately $23 \%$ to $91 \%$ of umbilical cords that are not treated using antiseptics will be infected by Staphylococcus aureus during the first 72 hours after birth. ${ }^{15}$ These bacteria can cause pustules, conjunctivitis, pyoderma, and omphalitis or umbilical cord infections. Without treatment, death may occur within few days. ${ }^{9,12-15}$

The umbilical cord is usually separated from the body between 5 and 15 days after birth. Before the umbilical cord is separated, the remaining stump can be considered as undergoing the wound healing process and thus become a route that makes it possible for blood vessel to be infected and for the infection to be spread through the infant's bloodstream. ${ }^{10,14,16}$ Poor cord care causes a long delay in umbilical cord separation. ${ }^{12}$ This delay of umbilical cord separation can increase the risk of infection. ${ }^{12-15}$

Dry cord care after birth is endorsed by the American Academy of Pediatrics (AAP) and the World Health Organization (WHO) although many recent studies have found colonization rates of Staphylococcus aureus to be high in infants who do not receive topical antimicrobial on the cord. ${ }^{5,6}$ The method that is currently being developed for the umbilical cord is umbilical cord care using topical breast milk. Applying breast milk to umbilical cord stump is one of the traditional cord care practices in Turkey, Kwazula Natal, and some communities in Kenya. ${ }^{6,13,14}$ According to WHO, this approach may be useful given the anti-bacterial factors as well have various immunological and anti-infectious agents found in breast milk. Colostrum also contains a significant number of complementary components that act as natural antimicrobial agents and protective factors that provide specific and nonspecific passive immunity. ${ }^{12-15}$ Use of topical breast milk containing colostrum in cord care is effective to reduce the colonization of pathogenic organisms (Staphylococcus) in the umbilical cord compared to not using antimicrobial or dry technique. ${ }^{17,18,19}$ This study aimed to compare umbilical cord separation time and incidence of omphalitis in the application of topical breast milk, open dry, and closed dry techniques in newborn umbilical cord care.

\section{Methods}

This was a quantitative post-test only group quasiexperimental study conducted in June-August 2018 in Ciruas Public Health Center, Serang District, Banten Province, Indonesia. In this study, 120 newborns aged 0 days up to 2 days post-cord separation were sampled consecutively and divided into groups of 40 newborns.

1. The inclusion criteria were:

a. newborns with a gestational age of 37-42 weeks;

b. healthy with an APGAR score of $>7$ in minutes 1 and 5

c. newborn weight of 2,500-4,000 grams;

d. mother of the newborn has received complete TT (tetanus toxoid) immunization;

e. mother had produced milk when the baby was born.

2. The exclusion criteria were:

a. history of labor with premature rupture of membranes;

b. history of asphyxia and newborns with abnormalities.

Data collected in this study were the umbilical cord separation time and incidence of omphalitis in groups applying different umbilical cord care techniques, i.e. umbilical cord care using breast milk, open dry technique, or closed dry technique. In the study, all the infant's parents got information about the procedures and rules applied during the study and consent was sought for infant participation in the study. Infant mothers signed the informed consent form.

In this study, newborns were divided into three cord care groups. The first intervention group received topical breast millk umbilical cord care that was applied every 12 hours ( 2 times a day) up to 2 days after the umbilical cord 
was separated. The reason for continuing the application up to 2 days after the cord separation is because a small amount of mucosal material was still presence until the completion of healing process for a few days. The mother of the infant was given information about the importance of umbilical cord care, signs of infection of the umbilical cord, and to wash both hands properly using soap and running water before performing umbilical cord care. The researcher then explained the steps of umbilical cord care using breast milk which consisted of applying 4 to 6 drops of breast milk on base and end of umbilical cord stump and let it dry. The application of breast milk was performed every 12 hours ( 2 times a day) up to 2 days after cord separation. The mother was also asked to prevent umbilical cord from being soaked when bathing the infant.

The second intervention group performed cord care using the open dry technique. The mother of the infant was given information about the importance of umbilical cord care, signs of infection of the umbilical cord, and to wash both hands properly using soap and running water before performing umbilical cord care. The researcher then explained the steps of umbilical cord care using the open dry technique which consisted of leaving the umbilical cord clean and open without covering it with gauze up to 2 days after the cord was separated. If the umbilical cord was exposed to urine, mother was asked to simply clean the umbilical cord using high-level disinfection (HLD) water using clean cotton. The mother was cotton. The mother was also asked to prevent umbilical cord from being soaked when bathing the infant.

The third intervention group performed cord care using the closed dry technique. The mother of the infant was given information about the importance of umbilical cord care, signs of infection of the umbilical cord, and to wash both hands properly using soap and running water before performing umbilical cord care. The researcher then explained the steps of umbilical cord care using the closed dry technique which consisted of leaving the umbilical cord clean and dry by covering it with a sterile gauze up to 2 days after the cord is separated. released. If the umbilical cord was exposed to urine, mother was asked to simply clean the umbilical cord using high-level disinfection (HLD) water using clean cotton. The mother was cotton. The mother was also asked to prevent umbilical cord from being soaked when bathing the infant.

Assessment of the incidence of omphalitis and umbilical cord care techniques performed by respondents was conducted by the researchers with supports from village midwives. The assessment was performed through direct observation with reference to an observation form during home visits. The observation forms were developed for umbilical cord care using topical breast milk, open dry, and closed dry techniques to help the village midwives and parents in performing cord care. Measurement (observation) or posttest to assess umbilical cord infection (omfalitis) in the three intervention groups was conducted using a modified observation form from the REEDA scale wound healing measuring instrument.

Chi-square test was used to analyze the incidence of omphalitis while the differences in umbilical cord separation time between the three groups were performed using Kruskal Wallis Test and Mann Whitney tests. Data analysis was performed using SPSS version 21.0.

\section{Results}

As presented in table 1, the three intervention groups had similar characteristics (homogeneous) and therefore are comparable. Table 2 shows that the umbilical cord was separated sooner in the topical breast milk group, i.e. 3.2 days with a range of 2 to 5 days $(\mathrm{p}=0.000$, smaller than the alpha value of $<0.05$ ), showing significant differences in umbilical cord separation time between the three groups. In Figure 1, it is shown that the umbilical cord treated using topical breast milk experienced gangrene (dry black area) on the second day and then separated on the third day. The umbilicus became dried one day after the separation, which was faster when compared to the dry treatments. Table 3 presents significant differences in the incidence of omphalitis among the three umbilical cord care groups $(p=0.000$, smaller than the alpha value of 0.05 ). Table 4 reflects significant differences $(\mathrm{p}=0.000$, smaller than the alpha value of 0,05 ) between umbilical cord separation time of the three groups. An average of 2 days difference was found between the topical breast milk group and open dry group and an average of 4 days difference was found between the topical breast milk group and closed dry 
Table 1: Respondent Characteristics

\begin{tabular}{|c|c|c|c|c|c|c|c|c|c|}
\hline \multirow{2}{*}{ Characteristics } & \multicolumn{2}{|c|}{$\begin{array}{c}\text { Topical } \\
\text { Breast Milk } \\
\end{array}$} & \multicolumn{2}{|c|}{ Open Dry } & \multicolumn{3}{|c|}{ Closed Dry } & & \multirow[t]{2}{*}{ p value } \\
\hline & $\mathbf{N}$ & $\%$ & $\mathbf{N}$ & $\%$ & $\mathbf{n}$ & $\%$ & $\mathbf{N}$ & $\%$ & \\
\hline \multicolumn{10}{|l|}{ Infant birth weight } \\
\hline 1. $<3.500$ grams & 17 & 43 & 30 & 75 & 25 & 63 & 72 & 60 & 0.166 \\
\hline 2. $\geq 3,500$ gram & 23 & 57 & 10 & 25 & 15 & 37 & 48 & 40 & \\
\hline \multicolumn{10}{|l|}{ Parity } \\
\hline 1. Primipara & 7 & 18 & 9 & 22 & 8 & 20 & 24 & 20 & 0.000 \\
\hline 2. Multipara & 31 & 77 & 30 & 75 & 31 & 78 & 92 & 77 & \\
\hline 3. Grand multipara & 2 & 5 & 1 & 3 & 1 & 2 & 4 & 3 & \\
\hline \multicolumn{10}{|l|}{ Maternal age } \\
\hline 1. At risk & 4 & 10 & 4 & 10 & 11 & 38 & 19 & 16 & 0.281 \\
\hline 2. Not at risk & 36 & 90 & 36 & 90 & 29 & 72 & 101 & 84 & \\
\hline \multicolumn{10}{|l|}{ Maternal Education } \\
\hline 1. Low & 14 & 35 & 10 & 25 & 10 & 25 & 34 & 28 & 0.163 \\
\hline 2. Moderate & 23 & 57 & 29 & 72 & 28 & 70 & 80 & 67 & \\
\hline 3. High & 3 & 8 & 1 & 3 & 2 & 5 & 6 & 5 & \\
\hline
\end{tabular}

Table 2: Cord separation time

\begin{tabular}{ccccc}
\hline Cord Separation Time (in days) & $\begin{array}{c}\text { Topical Breast } \\
\text { Milk } \\
(\mathbf{n = 4 0 )}\end{array}$ & $\begin{array}{c}\text { Open Dry } \\
\text { Technique } \\
(\mathbf{n = 4 0 )}\end{array}$ & $\begin{array}{c}\text { Closed Dry } \\
\text { Technique } \\
(\mathbf{n}=\mathbf{4 0})\end{array}$ & p value \\
\hline $\begin{array}{c}\text { Median (SD) } \\
\text { Min -Max }\end{array}$ & $\begin{array}{c}3(0.79) \\
2-5\end{array}$ & $\begin{array}{c}5(0.93) \\
3-7\end{array}$ & $\begin{array}{c}7(1.42) \\
5-12\end{array}$ & 0.000 \\
\hline
\end{tabular}

Table 3: Omphalitis Incidence

\begin{tabular}{lccccc}
\hline & & & & \\
& Omphalitis & \multicolumn{2}{c}{ Without Omphalitis } \\
\cline { 2 - 5 } Groups & n & \% & n & \% & p value \\
\hline & & & & & \\
Topical Breast Milk & 0 & 0 & 40 & 100 & 0.000 \\
Open Dry Technique & 0 & 0 & 40 & 100 & 77 \\
Closed Dry Technique & 9 & 23 & 31 & \\
\hline
\end{tabular}

Table 4: Umbilical Cord Separation Time Comparison

\begin{tabular}{cccc}
\hline \multirow{2}{*}{ Description } & $\begin{array}{c}\text { Topical Breast Milk vs } \\
\text { Open Dry }\end{array}$ & $\begin{array}{c}\text { Topical Breast Milk vs } \\
\text { Closed Dry }\end{array}$ & $\begin{array}{c}\text { Open Dry vs Closed } \\
\text { Dry }\end{array}$ \\
\cline { 2 - 4 } & p Value & p Value & p Value \\
\hline $\begin{array}{c}\text { Median } \\
\text { Difference } \\
\text { (in days) }\end{array}$ & $0.000^{*}$ & $0.000^{*}$ & $0.000^{*}$ \\
\hline
\end{tabular}

group. Table 5 listed the correlation coefficients between umbilical cord separation time and infant birth weight with Open Dry group as the group with the strongest correlation. The correlation coefficient of 0.33 and $p$ value of 0.034 in this group showed a significant 
correlation between umbilical cord separation time and infant birth weight.
Physiologically, the white color of the umbilical cord disappears in 24 hours to turn into brownish yellow and

Table 5 Correlation between Cord Separation Time and Infant Birth Weight

\begin{tabular}{lccc}
\hline Variables & N & Correlation Coefficient(r) & p Value \\
\hline Topical Breast Milk & 40 & 0.14 & 0.388 \\
Open Dry & 40 & 0.33 & $0.034^{*}$ \\
Closed Dry & 40 & 0.28 & 0.081 \\
\hline
\end{tabular}

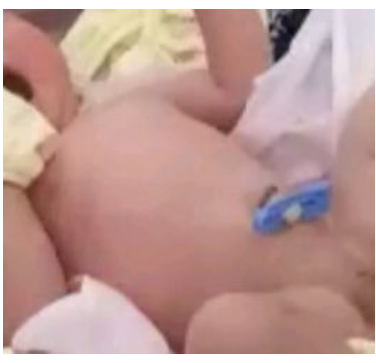

Day 1

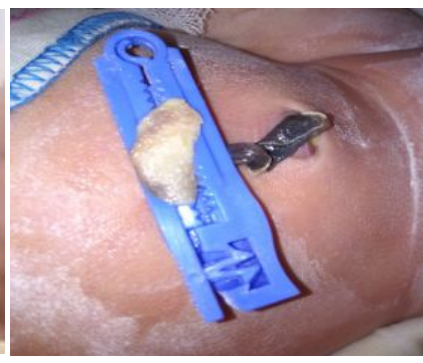

Day 2

Figure 1: Umbilical cord in topical breast milk group

\section{Discussion}

This study found that the average umbilical cord separation time in the topical breast milk group was 3 days, 2 days faster than the time needed in the open dry technique and 4 days faster than in the closed dry technique. This result indicates that umbilical cord care using topical breast milk is the best and fastest umbilical cord care method when compared to dry treatments.

In topical breast milk umbilical cord care, the umbilical cord is also left open for air exposure. The additional antibacterial, antiviral, and antimicrobial properties contained in breast milk combined with air exposure helps to accelerate the necrosis process of the umbilical cord.

Umbilical cord care using open dry technique as recommended by the Ministry of $\mathrm{Health}^{20}$ shows an umbilical cord care separation of 2 days faster than in the closed dry technique, thus reducing the risk for omphalitis. To make the cord separates faster, air exposure is needed to make water contained in Wharton's jelly dries quickly. This will accelerate umbilical cord separation when compared to the closed dry umbilical cord care technique as air in this technique is hindered by the gauze, leading to the need for longer time to dry and separate.

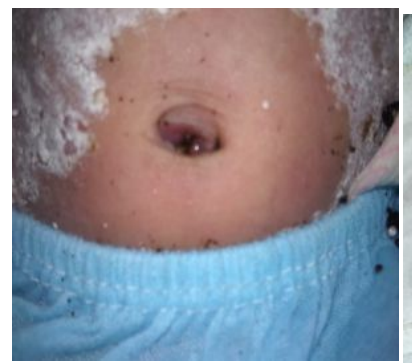

Day 3

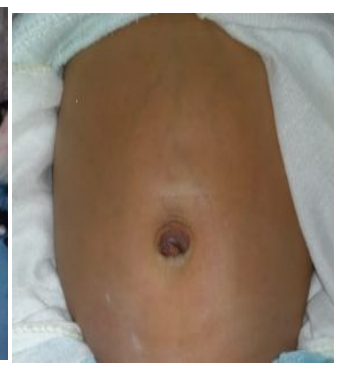

Day 1 after cord separation then dries into black and stiffen cord. In a few days, the umbilical cord stump will experience necrosis forming a small granulation wound that will form the umbilicus after recovery. ${ }^{21,22}$ If the base of the umbilical cord is clean, the risk of infection is reduced and the umbilical cord will dry faster. ${ }^{16}$

Breast milk can accelerate the process of cord separation through the interaction with cord polymorphonuclear leucocytes, enzyme photolysis, and other immunological compounds. ${ }^{6,13}$ Umbilical cord care using topical breast milk reduces bacterial colonization and accelerates the umbilical cord separation, which is faster than in the dry technique. ${ }^{6,18}$

Breast milk is a natural antiseptic agent that will not destroy non-pathogenic germs. Topical use of breast milk containing colostrum in cord care is effective to reduce colonization of pathogenic organisms (Staphylococcus) in the umbilical cord when compared to not using any antimicrobial agents or dry technique application. ${ }^{17,18,19}$ Farahani et al. ${ }^{18}$ stated that the most abundant bacteria found in cord stump are $S$. epidermidis, S. aureus, E. Coli, and Klebsiela pneumoniae. The mean bacterial colonies found on the umbilical cord treated with dry clean method are higher than in the umbilical cord treated with colostrum. 
The results of this study indicate that umbilical cord care using topical breast milk (ASI) and open dry technique can better prevent omphalitis when compared to the closed dry technique. This is due to the faster umbilical cord separation in both techniques which reduce the risk for infection.

Omphalitis or umbilical cord infection can be caused by bacteria that enter the body through the umbilical cord due to the use of unsterile umbilical cord cutting instrumen, skin-to-skin contact between mother and infant, improper hand-washing technique, poor umbilical cord care, and nosocomial infections. ${ }^{6,10,23}$

Before the umbilical cord separates from the infant, the remaining stump can be considered as undergoing the wound healing healing and thus becomes a route for infection to enter the baby's bloodstream through the blood vessels. ${ }^{9,14,17}$ Poor umbilical cord care will delay umbilical cord separation. ${ }^{13}$ Delayed umbilical cord separation can increase the risk of infection. ${ }^{12-15}$ Rapid separation of the umbilical cord can reduce the risk of cord infection because the cord as a vulnerable area for colonization of germs only stays for a short time on the infant's body.

Efforts can be made to reduce the risk of infection by applying breast milk on the umbilical cord. According to Mullany et al. ${ }^{12}$ breast milk, when applied on umbilical cord, is effective to reduce the risk for infection on the cord because breast milk contains IgA, IgG, and IgM as anti-infection agents. Breast milk also contain nonimmunoglobulin elements such as lactoferrin and lysoenzymes that have antibacterial, antiviral, or antimicrobial natures that also function as antiinflammation agents. This supports the notion that breast milk can be used as a natural antiseptic alternative to accelerate cord separation without damaging normal flora on the cord as well as preventing cord infection (omphalitis).

Breast milk is a source of two main growth factors, namely alpha and beta transformation growth factors (TGF-A and TGF-B), and insulin growth factors 1 and 2 (IGF-1 and IGF-2) ${ }^{6,13,18,19}$ These growth factors stimulate muscle and cartilage repair as well as stimulating wound healing process. ${ }^{6,13,18}$ Alpha and beta transformation factors (TGF-A and TGF-B) are involved in normal cell activities such as embryonic development, cell proliferation, and tissue repair. Insulin growth factor 1 (IGF-1) has anabolic properties and also wound healing characteristics. Insulin growth factor 1 (IGF-1) slows down catabolism and is the only growth factor that can stimulate growth and muscle repair by itself. ${ }^{6,13}$ In the topical breast milk and closed dry cord care groups, no correlation was established between umbilical cord separation time and infant birth weight. This may be due to the influence of the topical breast milk and closed dry cord care technique that affect umbilical cord separation time.

In contrast, a quite strong correlation between the time of umbilical cord separation and infant birth weight was seen in the open dry technique group that did not cover the cord with gauze or administer antiseptics on the cord, leading to physiological cord separation process in which infant birth weight may influence the cord separation time. The reason is because umbilical cord contains Wharton's jelly that maintains the wet state of the cord. The drying of the cord is very much influenced by the loss of water content in the jelly. Hence, the bigger the cord size is, the longer the time needed until separation. Infants with high birth weight will have bigger cords which take a longer time to dry.

Wharton's jelly is a jelly-like substance that plays a role as a mucoid connective tissue. The loss of water content from the jelly leads to mummification of the umbilical cord as soon as the baby is born. This process is greatly aided by air exposure. ${ }^{22,24}$

Term infants have a normal Wharton's jelly size as evident from the results of a study by Wibowo et al. ${ }^{25}$ stating that the mean area of Wharton's jelly in term pregnancy with normal birth weight is $56.077 \pm 19.537$ $\mathrm{mm}^{2}$ with a correlation between the size of Wharton's jelly area and term infant birth weight.

\section{Conclusion}

It is concluded from this study that the cord separation time in umbilical cord care using topical breast milk is shorter than those of the open dry technique and closed dry technique with the mean cord separation time of 3.2 days, ranging from 2 to 5 days, in topical breast milk group. No omphalitis was found in groups applying topical breast milk and open dry techniques. However, 9 cases of omphalitis were found in the group applying closed dry technique. 
Conflict of interest: None. Disclaimer: Nil.

\section{References}

1.Blencowe H, Cusens S, Mullany LC, Lee AC, Kerber K, Wall S, et al. Clean birth and postnatal care practices to reduse neonatal death from sepsis and tetanus: a systematic review and Delphi estimation of mortality effect. BMC Public Health. 2011;11(Suppl 3): S11.

2.Black RE, Cousens S, Johnson HL, Lawn JE, Rudan I, Bassani DG, et al. Global, regional and nationalcauses of child mortality in 2008: a systematic analysis. Lancet. 2010; 375(9730):1969-87.

3.Yefri R, Mayetti, Machmud R. Kolonisasi kuman dan kejadian omphalitis pada tiga regimen perawatan tali pusat pada bayi baru lahir. Sari Pediatri. 2010; 11(5): 341-7.

4.Salam A. Kesehatan bayi baru lahir. Jakarta: Rajawali Pers; 2008.

5.WHO. Importance of cord care. [Cited on 18 February 2018]. Available from: http:who.int/reproductivehealth/publication.

6.Allam NA, Wafa A, Megrin AL, Talat AM. The effect of topical application of mother milk on separation of umbilical cord for newborn babies. Am J of Nursing Sci. 2015; 4(5): 288-96.

7.Sodikun. Buku saku perawatan tali pusat. Jakarta: EGC; 2009.

8.Depkes RI. Buku panduan tatalaksana bayi baru lahir di rumah sakit. Jakarta: Depkes RI; 2010.

9.Quattrin R, Lacobucci K, Tina ALD, Galina L, Pittini C, Brusaferro S. 70\% alcohol versus dry cord in the umbilical cord care. Medicine. 2016; 95(14): e3207.

10.Imdad A, Mullany LC, Bqui AH, Arifeen SE, Tielsch JM, Khatry SK, et al. The effect of umbilical cord cleansing with cholhexidine on omphalitis and neonatal mortality in community settings in developing countries: a meta-analysis. BMC Public Health. 2013;13 (Suppl 3): S15

11.Kementerian Kesehatan RI. Buku kesehatan ibu dan anak. Jakarta: Kemenkes dan JICA; 2011.
12.Mullany LC, Darmstadt GL, Katz J, Khatry SK, LeClerq $\mathrm{SC}$, Tielsch JM. Risk of mortality subsequent to umbilical cord infections among newborns of Southern Nepal: cord infection and mortality. Pediatr Infect Dis J. 2009; 28 : 17-20.

13.Aghamohammadi A, Zafari M, Moelemi L. Comparing the effect of topical application of human milk and dry cord care on umbilical cord separation time in healthy newborn infants. Iran J Pediatr. 2012; 22(2): 158-62.

14.Abbaszadeh F, Hajizadeh Z, Jahangiri M. Comparing the impact of topical application of human milk and chlorhexidine on cord separation time in newborns. Pak J Med Sci. 2016; 32(1): 239-43.

15.Ayyildiz, Kulakci H, Ayoglu FN, Kalindi N, Veren F. The effect of two bathing methods on the time of separation of umbilical cord in term babies in Turkey. Iran Red Crescent Med J. 2015; 17(1): e19053.

16.American Academy of Pediatrics. Infections control. In: American Academy of Pediatrics, American college of obstetricians, Gynecologist, ed. Guidelines for perinatal care. 3rd ed. Elk Grove Village, IL: American Academy of Pediatrics; 192:141-75.

17.WHO. Care of the umbilical cord: A review the evidence. 1998. [Cited on 18 February 2018]. Available at: http://www.who.int/reproductivehealth/publications/MSM98-4.

18.Farahani LA, Muhammadzadeh A, Tafazzoli M, Esmaeliet H, Ghazvinni K. Effect of topical application of breast milk and dry cord care on bacterial colonization and cord separation time in neonates. J Chinese Clin Med. 2008; 3(6): 327-32.

19.Munasi Z, Nia K. Air susu ibu dan kekebalan tubuh. Dalam: Bedah ASI Editor: Badriul Hegar, Rulina Suradi, Aryono Hendarto, I Gusti Ayu Pratiwi. Jakarta: IDAI; 2009

20. Wibowo N, Saifudin AB. Plasenta, tali pusat, selaput janin, dan cairan amnion. Jakarta: FKUI; 2008.

21.Cunningham, et al. Obstetri Williams (Williams Obstetri). 24th Edition. Jakarta: EGC; 2014. 
The New Indian Journal of OBGYN. 2019 (July-December); 6(1)

22.Lumsden H. Examination of newborn. In: Lumsden H, Holmes D, Editor Care of the newbornby ten teachers. London: Hodder Arnold; 2011: 34-50.

23.Kasiati, Santoso B, Yunitasari E, Nursalam. Topikal ASI: model asuhan keperawatan tali pusat pada bayi. J Ners. 2013; 8(1): 9-16.

24.Williamson A, Crozier K. Buku ajar asuhan neonatus. Jakarta: EGC; 2013

25.Wibowo AP, Pramono BA, Miranti IP. Korelasi luas area wharton's jelly dengan luaran berat lahir bayi pada kehamilan cukup bulan. JKD. 2017; 6(2): 196-205.

2015;5(3): 174-77.

Rina Kartikasari ${ }^{1}$, Hidayat Wijayanegara ${ }^{2}$, Osman Syarief ${ }^{3}$

1,2,3 Student of Applied Midwivery Master Program of STIKes Dharma Husada, Applied Midwivery master Program of STIKes Dharma Husada, Health Polytechnic of Bandung 